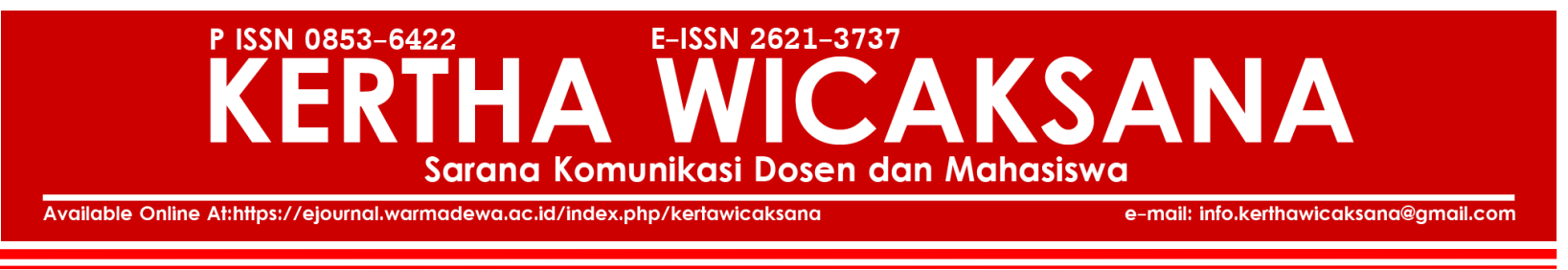

\title{
Tanggungjawab Hukum Bank Terhadap Nasabah dalam Hal Terjadinya Kegagalan Transaksi pada Sistem Mobile Banking
}

\author{
I Made Aditya Mantara Putra \\ Fakultas Hukum Universitas Warmadewa, Denpasar, Bali-Indonesia \\ adityamantara@yahoo.co.id
}

Published: 30/07/2020

How To Cite:

Putra, I. M. A. M. (2020). Tanggungjawab Hukum Bank Terhadap Nasabah dalam Hal Terjadinya Kegagalan Transaksi pada Sistem Mobile Banking. KERTHA WICAKSANA: Sarana Komunikasi Dosen dan Mahasiswa. 14(2). Pp 132-138. https://doi.org/10.22225/kw.14.2.1921.132-138

\begin{abstract}
Abstrak
Dijaman era global milenial ini tentu kita mengenal istilah mobile banking. Dalam hal ini sistem tersebut merupakan suatu sistem pada media elektronik yang memiliki manfaat untuk promosi oleh pihak bank dan sekaligus melakukan segala sesuatu yang berkaitan dengan transaksi online. Adapun penelitian ini menganalisis 2 pokok permasalahan yaitu: pertama tentang bagaimanakah bentuk perlindungan terhadap nasabah dalam melakukan transaksi dengan sistem mobile banking, dan yang kedua yaitu tanggung jawab hukum pihak bank dalam hal terjadinya kegagalan transaksi dalam transaksi dengan menggunakan sistem mobile banking. Penelitian ini menggunakan jenis penelitian secara normatif, yaitu suatu penelitian beranjak dari adanya kekosongan norma, kekaburan norma ataupun konflik norma. Permasalahan dikaji dengan mempergunakan interpretasi hukum, serta kemudian diberikan argumentasi secara teoritik berdasarkan teori-teori dan konsep hukum yang ada. Hasil penelitian menunjukkan bahwa terhadap nasabah dalam bertransaksi dengan sistem mobile banking walaupun belum ada ketentuan yang mengatur tentang perlindungan hukum secara khusus nasabah tetap diberikan perlindungan hukum baik preventif maupun represif oleh ketentuan-ketentuan yang ada dalam peraturan perundang-undangan yang berkaitan dengan bank dan perlindungan konsumen. Terhadap permasalahan kedua yaitu bentuk pertanggungjawaban pihak bank sebagai pelaku usaha apabila terjadi kerugian nasabah dalam transaksi dengan sistem mobile banking adalah bank bertanggung jawab penuh untuk memberikan penggantian kerugian terhadap nasabah jika kesalahan ini memang betul dan terbukti dikarenakan sistem yang ada pada pihak bank.
\end{abstract}

Kata Kunci: Perlindungan Hukum, Nasabah, Transaksi Mobile Banking, Pertanggungjawaban Bank

\begin{abstract}
In this era of millennial global era, of course we are familiar with the term mobile banking. Mobile banking is one of the ways in which internet is used for promoting and making transactions of traditional products such as opening deposit account, transferring funds to another account as well as new banking products such as claims through the bank websites. Two problems are formulated in this study. The first problem is how the costumers are legally protected when they make transactions trough mobile banking, to what extend the bank is responsible for the loss possibly resulting from any transaction through the mobile banking. This study is classified as a normative legal study. What is meant is that the data needed was obtained by library research, meaning that the data was obtained from the secondary sources. The problem were analyzed using legal interpretation followed by theoretical argument based on the legal theories and concepts available. The results of the study show that the customers in transacting with the mobile banking system even though there are no provisions governing legal protection specifically, customers are still given legal protection both preventive and repressive by the provisions contained in the legislation relating to banks and consumer protection. The results of the study show that the customers in transacting with the mobile banking system even though there are no provisions governing legal protection specifically, customers are still given legal protection both preventive and repressive by the provisions contained in the legislation relating to banks and consumer protectionThe bank will be responsible for providing compensation for any loss experienced by the customers resulting from the internet banking system, if the error made by the bank.
\end{abstract}


Keywords: Legal protection, customer, mobile banking transaction, responsibility of bank.

\section{PENDAHULUAN}

Dewasa ini pemakaian internet dan bisnis melalui internet berkembang sangat pesat. Tidak seorangpun pernah membayangkan bahkan perintisnya sendiri, bahwa internet akan mengalami perkembangan yang sedemikian spektakuler seperti sekarang ini. Perkembangan yang sangat pesat ini telah membawa berbagai kemudahan dalam kegiatan yang berkaitan dengan transaksi-transaksi bisnis. Transaksi bisnis yang dimaksudkan dalam penelitian ini mengaitkan dengan kegiatan dalam dunia perbankan khususnya di Indonesia yang dapat diwujudkan dalam bentuk sistem electronic banking. Berbagai kemudahan dapat dinikmati oleh nasabahnya seperti penawaran jasa perbankan melalui situs-situs yang terdapat pada sistem e-banking tersebut sampai dengan tawaran untuk melakukan kegiatan transaksi secara online yang sering kita kenal dengan istilah mobile banking.

Sebagaimana diketahui dalam melakukan transaksi elektronik kerugian karena pembobolan rekening sangat banyak terjadi dengan melalui akses yang tidak sah ataupun tidak dikenal yang dialami oleh para nasabah. Dalam hal ini pihak bank seringkali mengelak dari tanggungjawabnya. Hal tersebut dikarenakan dalam sistem perbankan dikenal asas nonrepudiation (nir sangkal) yang memiliki pengertian sederhana yaitu nasabah tidak dapat menyangkal bahwa tidak pernah melakukan transaksi apabila sistem yang dimiliki oleh pihak bank telah mencatatnya. Hal ini berarti ketika terjadi kerugian pada nasabah akibat pembobolan rekening, pihak bank menyatakan bahwa jika transaksi terbukti dan sah karena rekening tersebut dibuka oleh seseorang yang berhak/ memiliki hak untuk membukanya.

Maksud dari yang berhak tersebut artinya yang mempunyai password menurut Roy Suryo, namun belum tentu yang mengetahui password tersebut belum tentu pemilik asli (Djumhana, 2000). Kasus di atas hanyalah salah satu contoh kasus di masa lalu, yang belum dapat dijerat sebagai cyber crime, karena belum adanya undang-undang khusus untuk menindaknya. Walaupun sekarang hukum positif di Indonesia sudah dapat menjerat terjadinya cyber crime, tetapi masih belum optimal. Disamping itu terhadap nasabah yang mengalami kegagalan transaksi juga harus diperhatikan, dengan mana nasabah mengalami kegagalan dalam bertransaksi mobile banking, akibat koneksi dari sistem mobile banking terputus atau dengan kata lain pada kenyataannya saat nasabah menekan tombol "ok" untuk mentransfer ataupun melakukan pembayaran tagihan telepon, air ataupun pembayaran lainnya, sistem menjawab transaksi tersebut gagal ataupun timed out, namun pada kenyataannya saldo tabungan yang dimiliki nasabah terpotong dan bukti pembayarannya pun tidak ada. Dilihat dari kasus tersebut diatas, undang-undang yang terkait dengan perlindungan konsumen yang saat ini berlaku di Indonesia, masih dapat dikatakan belum berbasis kepada yang sifatnya virtual, namun masih berbasis pada sesuatu yang sifatnya fisik.

Banyaknya kasus-kasus yang mengakibatkan kerugian materiil, sebagai akibat penggunaan layanan mobile banking, menunjukkan masih kurangnya suatu perlindungan hukum nasabah bank pengguna mobile banking. Dilihat dari hal ini maka dapat dinyatakan bahwa suatu konsekuensi pada kegiatan praktek perbankan, masih dapat dikatakan belum ada aturan yang mengkhusus mengenai pengaturan tentang traksaksi mobile banking ini.

Peraturan yang berlaku di Indonesia mengenai transaksi elektronik dapat kita lihat dalam Undang-Undang No. 19 Tahun 2016 Tentang Informasi dan Transaksi Elektronik (ITE) sudah diundangkan sejak tanggal 25 November 2016. Dilihat dari hal tersebut maka peraturan tersebut sudah memiliki kekuatan mengikat untuk dipatuhinya segala norma-norma yang sudah disepakati.

Eksistensi Undang-Undang Nomor 19 tahun 2016 Tentang ITE merupakan bentuk antisipasi bangsa Indonesia menghadapi kecendrungan global. Didalam Undang-Undang ini dijelaskan mengenai sanksi pidana, perdata ataupun denda. Undang-undang ini juga dapat dikatakan menerapkan asas non penal yaitu pemberdayaan peran partisipasi masyarakat untuk melakukan tindakan preventif (Sunarso, 2009).

Jika dilihat dari hal-hal tersebut maka masalah keamanan dapat dikatakan masih mengganjal dalam kegiatan bisnis khususnya terkait dengan sistem mobile banking ini, secara yuridispun juga masih belum jelas pengaturannya terkait dengan jaminan kepastian hukumnya. Adapun aspek yang 
menjadi pokok permasalahan dalam menggunakan sistem mobile banking antara lain : masalah kerahasiaan pesan (confidentiality), masalah bagaimana keutuhan (integrity) pesan tersebut terjamin sampai ke penerima, masalah keabsahan (authenticity) pelaku transaksi, dan masalah keaslian pesan agar dapat dijadikan barang bukti (Riswandi, 2005). Hal ini belum diatur secara khusus dalam Undang-Undang Nomor 19 Tahun 2016 tentang Informasi Dan Transaksi Elektronik, tetapi perlindungan secara umum dapat kita temukan dalam beberapa pasal yaitu pada pasal 7 , pasal 26 , pasal 28 ayat (1), pasal 30, pasal 31, pasal 32, pasal 3335,36 yang menjelaskan mengenai perbuatan-perbuatan dilarang dalam bertransaksi elektronik. Pelanggaran terhadap ketentuan-ketentuan tersebut dapat dijatuhkan sanksi perdata maupun sanksi pidana dan/ atau denda.

Jika dilihat dari ketentuan Pasal 7 tersebut di atas, dapat dikatakan pasal tersebut tidak jelas atau dengan kata lain pasal tersebut dinyatakan norma kabur, oleh karena bila dikaitkan dengan penelitian ini, untuk mewujudkan hak-hak dari nasabah untuk mendapatkan perlindungan hukum, informasi yang ada padanya berasal dari sistem elektronik yang memenuhi syarat berdasarkan undang-undang. Sedangkan sampai saat ini belum adanya aturan perundangundangan yang jelas dan secara khusus mengatur mengenai perlindungan hukum terhadap nasabah dalam hal terjadinya kegagalan transaksi yang diakibatkan karena koneksi terputus serta bentuk perundang-undangan seperti apa yang digunakannya.

Pada penelitian sebelumnya, (Maulina, Dahlan, \& Mujibussalim, 2016) menemukan adanya upaya hukum dalam mengatasi segala permasalahan yang timbul dari penggunaan ebanking melalui lembaga arbitrase. Pengguna ebanking mendapatkan keuntungan dan kemudahan, disamping adanya resiko. Nasabah yang mengalami kerugian materil tersedianya mekanisme pengaduan secara aturan. Kesalahan bank mengakibatkan kerugian nasabah, pihak bank akan bertanggung jawab dan melakukan ganti kerugian. Hasil penelitian lainnya oleh (Rahman, 2016) menemukan bentuk pertanggung jawaban terhadap penggunaan internet banking apabila terjadi masalah tergantung pada penyebab kerugian, apabila ternyata kerugian materiil yang diderita oleh nasabah bank pengguna internet banking diakibatkan oleh karena kesalahan dan pihak bank, maka pihak bank bertanggung jawab memenuhi tuntutan nasabah memberikan ganti kerugian.

Dilihat dari hal tersebut maka penulis meneliti mengenai pokok permasalahan tersebut yaitu bagaimana bentuk perlindungan hukum nasabah dalam melakukan transaksi bisnis terkait dengan sistem mobile banking dan bagaimana tanggung jawab hukum pihak bank dalam hal terjadinya kegagalan bertransaksi dengan system mobile banking.

\section{METODE}

Penelitian merupakan suatu kegiatan ilmiah yang berkaitan dengan analisa dan konstruksi yang dilakukan secara metodeologis, sistematis, dan konsisten (Soekanto, 1984). Penelitian hukum merupakan suatu kegiatan ilmiah, yang didasarkan pada metode, sistematika dan pemikiran tertentu, yang bertujuan untuk mempelajari satu atau beberapa gejala hukum tertentu, dengan jalan menganalisanya (Soekanto, 1984). Jenis penelitian yang digunakan dalam tulisan ini adalah jenis penelitian hukum normatif. Penelitian hukum normatif dilakukan dengan cara meneliti bahan hukum primer, bahan hukum sekunder dan bahan hukum tersier. Perlunya penelitian hukum normatif ini adalah beranjak dari adanya kekaburan norma hukum berkaitan permasalahan penelitian, sehingga dalam mengkajinya lebih mengutamakan sumber data sekunder, yang berupa bahan hukum primer dan bahan hukum sekunder.

\section{HASIL DAN PEMBAHASAN}

\section{Perlindungan Hukum Terhadap Nasabah Dalam Melakukan Transaksi Dengan Menggunakan Sistem Mobile Banking}

Pemanfaatan teknologi Komputer, telekomunikasi dan informasi perbankan yang diwujudkan melalui mobile banking, merupakan salah satu bentuk strategi perbankan untuk menarik animo masyarakat untuk menjadi nasabah bank. Fasilitas perbankan yang mempergunakan kecanggihan daripada teknologi menimbulkan permasalahan yang beresiko cukup tinggi sehingga dapat menimbulkan kerugian materiil bagi nasabahnya. Dalam hal ini bank merupakan salah satu lembaga yang sangat tergantung dan mengutamakan kepercayaan nasabah ataupun masyarakat, harus mampu menjaga kepercayaan tersebut dengan memberikan perlindungan hukum terhadap kepentingan masyarakat, terutama kepentingan dari nasabah bank yang bersangkutan. 
Penerapan mengenai pengaturan perlindungan terhadap nasabah seringkali merefleksikan tidak seimbangnya antara pihak bank dengan nasabahnya. Secara historisnya, nasabah dikatakan sebagai pihak yang lebih lemah dalam bertransaksi bisnis, dalam peraturan-peraturannya dan juga regulasi khusus apa saja yang dikeluarkan untuk melindungi kepentingan nasabah. Dalam bertransaksi menggunakan sistem mobile banking, menempatkan nasabah pada posisi yang lemah, oleh karena itu diperlukannya pengaturan hukum untuk menciptakan kepastian hukumnya dalam melakukan transaksi perbankan.

Poerwadarminta memberikan pemahaman mengenai pengertian daripada perlindungan hukum, yang berasal dari kata "lindung" yaitu menempatkan sesuatu agar tidak kelihatan, sedangkan perlindungan memiliki arti perbuatan melindungi, memberikan perlindungan kepada orang-orang yang dapat dikatakan lemah (Poerwadarminta, 2003). Dilihat dari penjelasan tersebut maka pengertian perlindungan hukum adalah suatu perbuatan yang mengatur dan melindungi hubungan antar subyek hukum. Adapun yang dimaksudkan subyek hukum tersebut adalah manusia ataupun badan hukum maupun jabatan yang merupakan bentuk daripada perbuatan hukum. Dalam hal ini masing-masing daripada subyek hukum tersebut merupakan pemikul hak dan kewajiban sesuai kemampuan dan kewenangannya.

Dari penjelasan tersebut diatas, maka dapat diketahu bahwa ada beberapa bentuk perlindungan hukum dalam transaksi mobile banking, yaitu :

1. Perlindungan hukum perjanjian Antara Bank Dengan Nasabah Pengguna Layanan Transaksi Mobile Banking;

2. Perlindungan Nasabah Dalam Transaksi Mobile Banking Dalam Kaitannya Dengan Hukum Perlindungan konsumen;

3. Perlindungan Hukum Preventif Dan Perlindungan Hukum Represif Terhadap Nasabah Perbankan Dalam Transaksi Mobile Banking

Menurut Philipus M. Hadjon, menyatakan bahwa "perlindungan hukum bagi rakyat dibedakan menjadi 2 macam, yaitu perlindungan hukum yang preventif dan perlindungan hukum yang represif. Perlindungan hukum yang preventif bertujuan untuk mencegah terjadinya sengketa, sedangkan sebaliknya perlindungan hukum yang represif bertujuan untuk menyelesaikan sengketa" (Hadjon, 1987). Perlindungan hukum preventif terhadap nasabah dalam transaksi dengan mobile banking yaitu melakukan upaya-upaya pencegahan yang merupakan kebijakan internal perbankan berupa pengawasan dan pembinaan terhadap bank-bank umum dalam melakukan transaksi elektronik (mobile banking).

Perlindungan hukum represif yaitu perlindungan hukum yang dilakukan dengan menerapkan sanksi terhadap pelaku agar dapat memulihkan hukum dalam keadaan yang sebenarnya. Perlindungan hukum represif dengan menggunakan sistem mobile banking secara khusus belum diatur dalam Undang-Undang Informasi Dan Transaksi Elektronik (UndangUndang No. 19 Tahun 2016) tetapi perlindungan hukum secara umum dalam transaksi elektronik dapat kita temukan daiam beberapa pasal yaitu: pasal 7, pasal 26,pasal 28 ayat (1), pasal 30, pasal 31 , pasal 32, pasal 33, 35, 36, yang termasuk perbuatan-perbuatan yang dilarang Pelanggaran terhadap ketentuan-ketentuan tersebut dapat dijatuhkan sanksi perdata maupun sanksi pidana dan/ atau denda.

Berdasarkan ketentuan pada penjelasan tersebut maka dapat diberikan sebuah simpulan bahwa Undang-Undang Nomor 10 Tahun 1998 Tentang perbankan mengatur perlindungan nasabah baik secara implisit maupun eksplisit. Implisit dalam artian disini memiliki arti bahwa adanya perlindungan yang dihasilkan melalui pembinaan dan pengawasan yang dilakukan oleh Bank Indonesia. Hal ini tertuang dalam Pasal 29 ayat (1) Undang-Undang Nomor 10 Tahun 1998 Tentang Perbankan. Sedangkan eksplisit dalam hal ini memiliki arti yaitu perlindungan yang terdapat dari pembentukan lembaga yang menjamin simpanan dana nasabah. Hal ini tertuang didalam Pasal, 37 B Undang-Undang Nomor 10 Tahun 1998 Tentang Perbankan.

\section{Tanggung Jawab Hukum Pihak Bank Dalam Hal Terjadinya Kegagalan Bertransaksi Dengan Sistem Mobile Banking}

Seperti yang kita ketahui mengenai transaksi elektronik sudah tidak asing lagi bagi masyarakat yang tinggal di wilayah kota khususnya Indonesia. Hal ini tidak terlepas dari maraknya dunia perbankan yang mempergunakan teknologi informasi dan media elektronik sebagai basis pelayanannya. Namun disisi lain dengan 
kecanggihan teknologi tersebut menimbulkan permasalahan-permasalahan yang menimbulkan kerugian terhadap nasabah dan resiko yang dapat dikatakan cukup tinggi, khususnya dalam bertransaksi menggunakan mobile banking ini. Disini terlihat bahwa masih kurangnya mengenai perlindungan hukum terhadap nasabah ataupun dapat dikatakan masih kurangnya penjelasan terhadap nasabah dan pemahaman oleh pihak bank terhadap perlindungan tersebut.

Dalam bertransaksi menggunakan sistem mobile banking ini sangat memberikan banyak kemudahan bagi nasabahnya dan merupakan salah satu cara yang efektif di jaman era global milenial seperti saat ini. Terlepas dari nilai lebihnya mengenai pelayanan mobile banking ini juga terdapat resiko yang masih belum jelas pengaturannya. Dengan kenyataan yang terjadi pada kasus-kasus yang disebutkan sebelumnya maka faktor keamanan disini harus menjadi fokus perhatian oleh pihak bank maupun nasabahnya. Bahkan seharusnya faktor keamanan inilah yang menjadi fitur unggulan yang ditonjolkan oleh pihak bank.

Usaha pengamanan untuk meningkatkan kepercayaan (trust) dari nasabah sudah dilakukan oleh pihak bank penyedia layanan mobile banking baik itu secara teknis maupun meningkatkan kesadaran terhadap pihak bank dan nasabah, membuat kebijakan dan prosedur yang baik serta selalu melakukan evaluasi terhadap sistem-sistem secara intens. Pengaman tersebut tentu merupakan usaha untuk memenuhi aspek-aspek keamanan seperti autentukasi, privasi, nonrepudiation dan ketersediaan (Syahputra, 2010). Jika dilihat perkembangan daripada teknologi ini, khususnya di Indonesia, masih banyak kasus yang terjadi terhadap nasabah yang memberikan kerugian secara materiil. Hal ini tentu memberikan pemahaman terhadap kita bahwa layanan mobile banking menunjukkan masih lemahnya perlindungan hukum nasabah pengguna layanan mobile banking \& internet banking (Mansur \& Gultom, 2005).

Masalah keamanan masih mengganjal dalam transaksi mobile banking, dan secara yuridis terkait juga dengan jaminan kepastian hukum. Terhadap permasalahan tersebut dan untuk memperoleh alasan dapat timbulnya suatu hak bagi terwujudnya perlindungan hukum terhadap nasabah terutama apabila nasabah dirugikan, dapat ditemukan dalam pasal 7 Undang-Undang No. 19 Tahun 2016 tentang ITE, yang menyebutkan bahwa:

"Setiap orang yang menyatakan hak, memperkuat hak yang telah ada, atau menolak hak orang lain, berdasarkan adanya informasi elektronik, dan/atau dokumen elektronik harus memastikan bahwa informasi elektronik yang ada padanya berasal dari sistem elektronik yang memenuhi syarat berdasarkan perundangundangan"

Jika dilihat ketentuan pasal 7 tersebut diatas, maka pasal tersebut dapat dinyatakan merupakan pasal yang normanya dapat dikatakan kabur atau tidak jelas, oleh karena maksud daripada penjelasannya secara sederhana yaitu untuk mewujudkan hak-hak tersebut bahwa informasi yang didapat ataupun yang ada padanya, berasal dari informasi atau sistem elektronik yang memenuhi syarat berdasarkan peraturannya. Sedangkan jika kembali melihat pada pemaparan sebelumnya, dapat dikatakan bahwa sampai saat ini belum ada aturan yang mengatur syarat-syarat sistem elektronik tersebut. Mengingat dalam sistem mobile banking dikenal adanya asas bahwa nasabah bank yang bersangkutan tidak dapat menyangkal bahwa nasabah tidak dapat menyangkal tidak melakukan transaksi apabila sistem telah mencatatnya atau non-repudiation (nirsangkal) (Djumhana, 2000). Dalam hal ini login akan berhasil dan dapat dilakukan apabila User ID dan PIN daripada nasabah tersebut dapat terinput dengan benar. Disini pihak bank tidak perduli apakah yang memasukan user ID dan PIN tersebut benar pemilik rekeningnya ataupun bukan. Apabila bukan pemilik rekeningnya, maka dirasa nasabah telah memberikan kepada yang bersangkutran untuk menggunakan user ID nya untuk bertransaksi.

Mekanisme login pada sistem mobile banking ini bahwa jika user ID dan PIN yang diinput atau dimasukkan salah, maka data nasabah tidak terverifikasi, sehingga login tidak bias dilakukan. Asas tersebut sangat menentukan terkait dengan saat dimana transaksi berlangsung serta mulai suatu kesepakatan (Djumhana, 2000). Disamping itu dalam kenyataannya, kegiatan cyber tidak lagi sederhana karena kegiatan tersebut tidak lagi dibatas oleh territorial suatu Negara. Kerugian ini dapat terjadi, baik terhadap pelaku transaksi ataupun kepada orang lain yang tidak pernah melakukan transaksi. Selain itu, pembuktian merupakan faktor yang dapat dikatakan sangat penting, oleh karena informasi elektronik masih belum terakomodasi pada sistem hukum acara di 
Indonesia secara komprehensif. Dilihat dari hal tersebut maka dampak yang diakibatkannya sangat komplek dan rumit.

Terkait dengan kerugian yang diderita nasabah pengguna layanan mobile banking, persoalan yang perlu dikaji adalah menyangkut tanggung jawab pihak-pihak dalam layanan mobile banking, atau dengan kata lain siapa yang akan bertanggung jawab terhadap kerugian yang diderita oleh nasabah pengguna layanan mobile banking, apakah pihak bank, nasabah atau pihak lain. Untuk itu maka melihat sistem hukum yang ada, kedudukan nasabah disini sangat lemah dibandingkan dengan pihak bank. Salah satu usaha demi terciptanya perlindungan dan meningkatkan kedudukan nasabah adalah dengan cara menerapkan prinsip tanggungjawab mutlak (strict liability) tentang tanggungjawab produsen yang dalam hal ini adalah pihak bank (Kristiyanti, 2008).

Pihak bank disini dalam pelaksanaannya sebagai produsen penyedia jasa layanan transaksi elektronik mobile banking, sudah sewajarnya dibebani dengan tanggungjawab mutlak, oleh karena resiko dalam transaksi menggunakan sistem mobile banking ini sangat tinggi dan bermacam-macam jenisnya. Sehingga disini bank dapat diberikan simpulan akan dapat lebih menerapkan prinsip kehati-hatiannya dalam melaksanakan pengunaan sistem mobile banking oleh penggunanya. Namun dengan pemberlakuan prinsip strict liability dalam hukum terhadap produknya, terutama terhadap pihak bank, bukan berarti pihak bank tidak mendapatkan perlindungan hukum, melainkan pihak bank diberi kesempatan untuk membebaskan dirinya terhadap tanggungjawab dalam hal tertentu yang dinyatakan dalam undang-undang maupun perjanjian yang telah disepakati. Adapun maksud dari hal tersebut adalah dalam hal nasabah tidak dapat membuktikan bahwa memang betul kesalahan dilakukan oleh sistem pihak bank, adanyaan keadaan yang memaksa, ataupun kelalaian pihak nasabah. Maka jika dilihat dari hal tersebut maka pihak bank akan bertanggungjawab penuh terhadap nasabah apabila nasabah yang melakukan transaksi mobile banking tersebut dapat memberikan pembuktian dalam hal terjadinya kegagalan transaksi yang dialaminya yang mengakibatkan kerugian materiil.

\section{SIMPULAN}

Perlindungan hukum bagi nasabah bank mengacu pada ketentuan pasal 7 Undang-Undang No. 19 Tahun 2016 tentang Informasi Teknologi dan Elektronik yang dapat dinyatakan tidak jelas pengaturannya, oleh karena pernyataan pada pasal tersebut memberikan pemahaman bahwa untuk mewujudkan hak-hak tersebut, informasi yang ada dan berasal dari sistem elektronik ini memenuhi syarat berdasarkan undang-undang yang ada, sedangkan pengaturannya mengenai transaksi mobile banking tersebut masih belum jelas adanya. Namun walaupun belum ada pengaturan secara khusus, nasabah perbankan tetap diberikan perlindungan hukum secara preventif dan represif. Perlindungan ini dilakukan bertujuan untuk mencegah terjadinya hal yang tidak dinginkan misalnya terjadinya sengketa yang mengaitkan ke pengadilan. Hal tersebut sangat dihindari oleh pihak bank, oleh karena kepercayaan bank terletak pada nasabah ataupun masyarakat sekitarnya. Selanjutnya tanggungjawab bank dalam hal terjadi kerugian nasabah dalam transaksi dengan sistem mobile banking adalah pihak bank sebagai pelaku usaha bertanggung jawab untuk memberi ganti rugi kepada nasabah apabila kesalahan dilakukan oleh pihak bank. Teteapi nasabah harus tetap memenuhi persyaratan nyang diminta oleh pihak bank untuk mempermudah pihak bank melakukan pengecekan terhadap transaksi mobile banking yang dinyatakan gagal tersebut.

Melihat permasalahan untuk kepastian hukum tentang berbagai aspek yang menyangkut transaksi mobile banking, utamanya aspek keamanan dalam melakukan transaksi dan tanggung jawab pihak bank dalam kerugian yang diderita nasabah sudah selayaknya dibuat suatu aturan khusus tentang transaksi mobile banking. Diharapkan pada masa yang akan datang dalam undang-undang Perbankan maupun dalam Peraturan terkait dengan Perbankan, ada ketentuan yang mengatur tentang bentuk-bentuk tanggung jawab bank yang mengkhusus dalam transaksi menggunakan sistem transaksi elektronik yang dalam hal ini adalah mobile banking, serta diharapkan pihak Bank Indonesia selaku pengawas sistem perbankan dapat melakukan pengawasan yang lebih baik terhadap bank-bank yang melakukan layanan mobile banking.

\section{DAFTAR PUSTAKA}

Djumhana, M. (2000). Hukum Perbankan Indonesia. Bandung: Citra Aditya Bakti. Retrieved from https://onesearch.id/Record/ IOS3774.JAKPU000000000013321 
Hadjon, P. M. (1987). Perlindungan Hukum Bagi Rakyat Indonesia. Surabaya: PT Bina Ilmu.

Kristiyanti, C. T. S. (2008). Hukum Perlindungan Konsumen. Jakarta: Sinar Grafika.

Mansur, D. M. A., \& Gultom, E. (2005). Cyber Law Aspek Hukum Teknologi Informasi. Bandung: PT Refika Aditama.

Maulina, S., Dahlan, \& Mujibussalim. (2016). Anggung Jawab Bank Terhadap Nasabah Yang Mengalami Kerugian Dalam Penggunaan Elektronik Banking. Kanun Jurnal Ilmu Hukum, 18(3), 353-365. Retrieved from http:// www.jurnal.unsyiah.ac.id/kanun/article/ download/5929/4883

Poerwadarminta, W. J. S. (2003). Disusun kembali oleh Pusat Bahasa Departemen Pendidikan Nasional. Jakarta: Balai Pustaka.

Rahman, U. B. (2016). Pertanggungjawaban Bank Terhadap Kerugian Nasabah Yang Terkait Dengan Fasilitas Transaksi Melalui Sms Bangking. Jurnal Nestor Magister Hukum, 1(1), 1-30. Retrieved from http://jurnal.untan.ac.id/ index.php/nestor/article/view/17235

Riswandi, B. A. (2005). Aspek Hukum Internet Banking. Jakarta: PT Raja Grafindo Persada.

Soekanto, S. (1984). Pengantar Penelitian Hukum. Jakarta: Universitas Indonesia.

Sunarso, S. (2009). Hukum Informasi Dan Transaksi Elektronik Studi Prita Mulyasari. Jakarta: Rineka Cipta.

Syahputra, I. (2010). Perlindungan Terhadap Konsumen Dalam Transaksi Elektronik. Bandung: Alumni. Retrieved from https:// opac.perpusnas.go.id/DetailOpac.aspx? $\mathrm{id}=317612$

Undang-Undang Nomor 10 Tahun 1998 Tentang Perbankan;

Undang-Undang Nomor 8 Tahun 1999 Tentang Perlindungan Konsumen;

Undang-Undang Nomor 19 Tahun 2016 Tentang Perubahan Atas Undang-Undang Nomor 11 Tahun 2008 Tentang Informasi dan Transaski Elektronik. 